Molecules 2001, 6, 230-243

\title{
molecules
}

ISSN 1420-3049

http://www.mdpi.org

\section{Synthesis of Acridine-based DNA Bis-intercalating Agents}

\author{
Gerard P. Moloney ${ }^{*}$, David P. Kelly ${ }^{2}$, P. Mack ${ }^{2}$ \\ ${ }^{1}$ The Austin Research Institute, Studley Road, Heidelberg, Victoria 3084, Australia. Fax (03) \\ 96884995. \\ ${ }^{2}$ University of Melbourne, Swanston Street Parkville, Victoria 3052, Australia. \\ *Author to whom correspondence should be addressed; e-mail: G.Moloney@ ari.unimelb.edu.au
}

Received: 12 July 2000; in revised form 30 August 2000 / Accepted: 18 January 2001/ Published: 28

February 2001

\begin{abstract}
Methods for the synthesis of $\underline{N}^{1}, \underline{N}^{8}$-bis(9-acridinyl)- $\underline{N}^{4}$-(4-hydroxybenzyl)spermidine and $\underline{N}^{1}, \underline{N}^{7}$-(hydroxybenzyl)-bis-(3-aminopropyl)amine were investigated. Thus monocyanoethylation of 4-methoxybenzylamine followed by treatment with 4chlorobutyronitrile gave the dinitrile $\underline{\mathrm{N}}$-(2-cyanoethyl)-N-(3-cyanopropyl)-4-methoxybenzylamine. Subsequent in situ reduction with lithium aluminium hydride gave the corresponding diamine. Biscyanoethylation of 4-methoxybenzylamine with 2 mole of acrylonitrile followed by reduction yielded the diamine $\underline{\mathrm{N}}, \underline{\mathrm{N}}$-bis-(3-aminopropyl)-4methoxybenzylamine. Both diamines reacted smoothly with 9-methoxyacridine to give the bis-(9-acridinyl) compounds 11 and 15 but with 4,5-dimethyl-9-methoxyacridine, the bis compound 16 was produced in only low yields. Demethylation of the dinitriles by a variety of approaches all failed to give the corresponding hydroxybenzyl derivatives. These studies yielded useful methylated tyrosine derivatives which could also be iodinated. This study has been useful for elucidating chemical methods needed for the synthesis of the desired tyrosine-based bis acridine compound and for alerting us to the need to synthesise a more labile protected tyrosine intermediate which will be easily deprotected to afford the desired tyrosine-based bis acridine compound.
\end{abstract}

Keywords: Acridine, intercalate, anti-cancer, synthesis. 


\section{Introduction}

Acridine (1) and its derivatives have long been a well established class of DNA and RNA binding compounds [1].<smiles>c1ccc2nc3ccccc3cc2c1</smiles>

These compounds have held the interests of biochemists and chemists for some years due to the possibilities of their clinical use. Many types of drugs are known to bind to DNA through intercalation between consecutive nucleotides in the DNA strand [2]. To this class of compounds belong several anti tumour agents of clinical importance such as actinomycin-D, daunomycin and adriamycin, as well as several drugs used in the treatment of parasitic diseases including quinacrine and ethidium bromide [3]. Thus the synthesis of acridine-derived DNA intercalating molecules that bind preferentially to particular nucleotide sequences appeared an exciting prospect. The mode of binding of acridine molecules involves intercalation of the acridine tricyclic ring between adjacent base pairs in the DNA duplex [4,5]. The acridine moieties are held in place by van der Waals forces supplemented by stronger ionic bonds to the phosphate ions of the DNA backbone (Scheme 1).
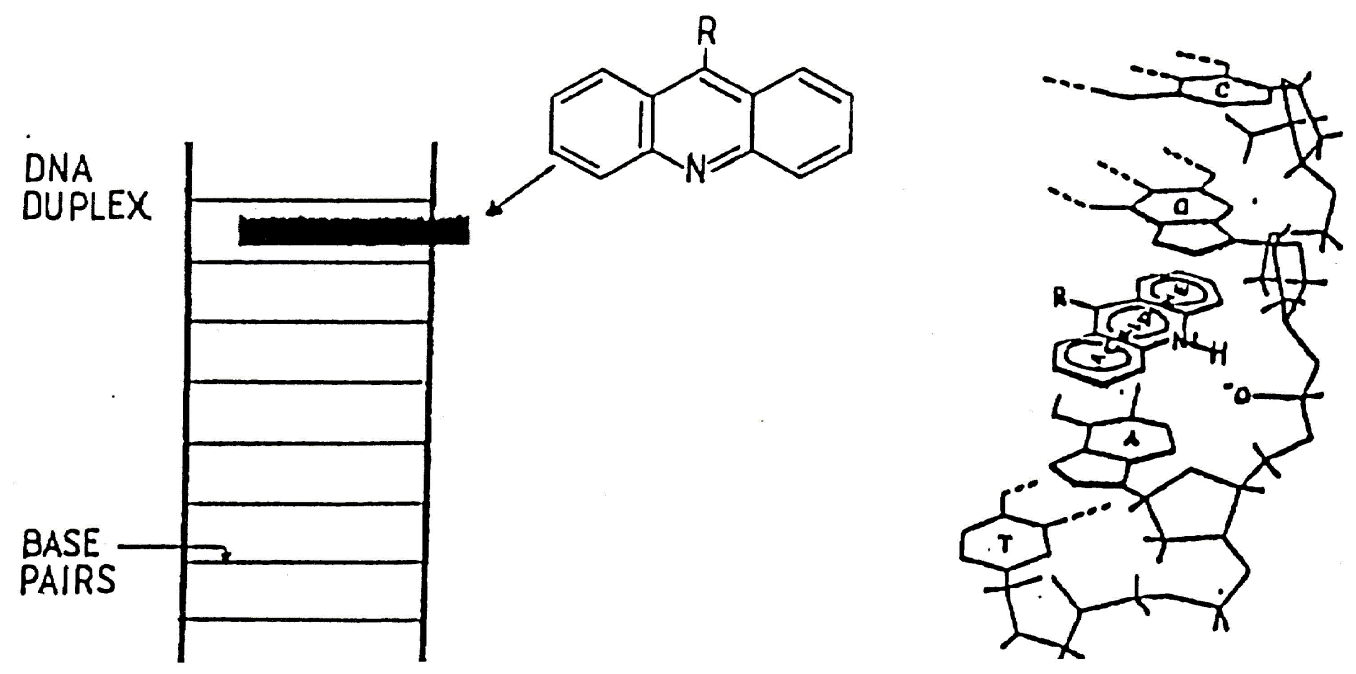

\section{Scheme 1}

It has been demonstrated by Hurwitz [6] that the binding of acridine molecules interferes with normal DNA function by blocking the DNA starter required by polymerases to synthesise RNA and DNA and hence inhibits protein synthesis. Considerable synthetic attention has been paid to substituted aminoacridines [7]. The incorporation of radioactively labelled iodine provides a method of determining the degree of ligand-DNA interaction, as well as any sequence selectivity. It has been shown the 125 I, covalently bound to pyrimidine bases in double stranded DNA or incorporated into a 
DNA binding compound through and iodine carrier, can cause scission of the DNA helix within three base pairs either side of the decaying atom [8]; the effectiveness of ${ }^{125} \mathrm{I}$ is a consequence of the intense radiochemical damage resulting from the emission of low energy Auger electrons [9].

Monoacridines have been shown to bind strongly to DNA. In more recent times however, it has been found that bifunctional intercalaters result in both higher affinity [10] and selectivity [11] of binding. The incorporation of ${ }^{125} \mathrm{I}$ is one method of determining the effectiveness and sequence selectivity of binding. ${ }^{125}$ I may be introduced into acridines if activating amine groups occupy the C3 and C-6 positions, directing iodination to the C-4 and C-5 positions respectively. Introduction of the activating amine group has been achieved through the nitro derivative [7], and coupling of the nitroacridines to the linker bis-amino compounds must occur at this stage. However, upon linking of the nitro acridines, reduction of the nitro functions to the corresponding amine functions proved to be difficult [12].

\section{Scheme 2}
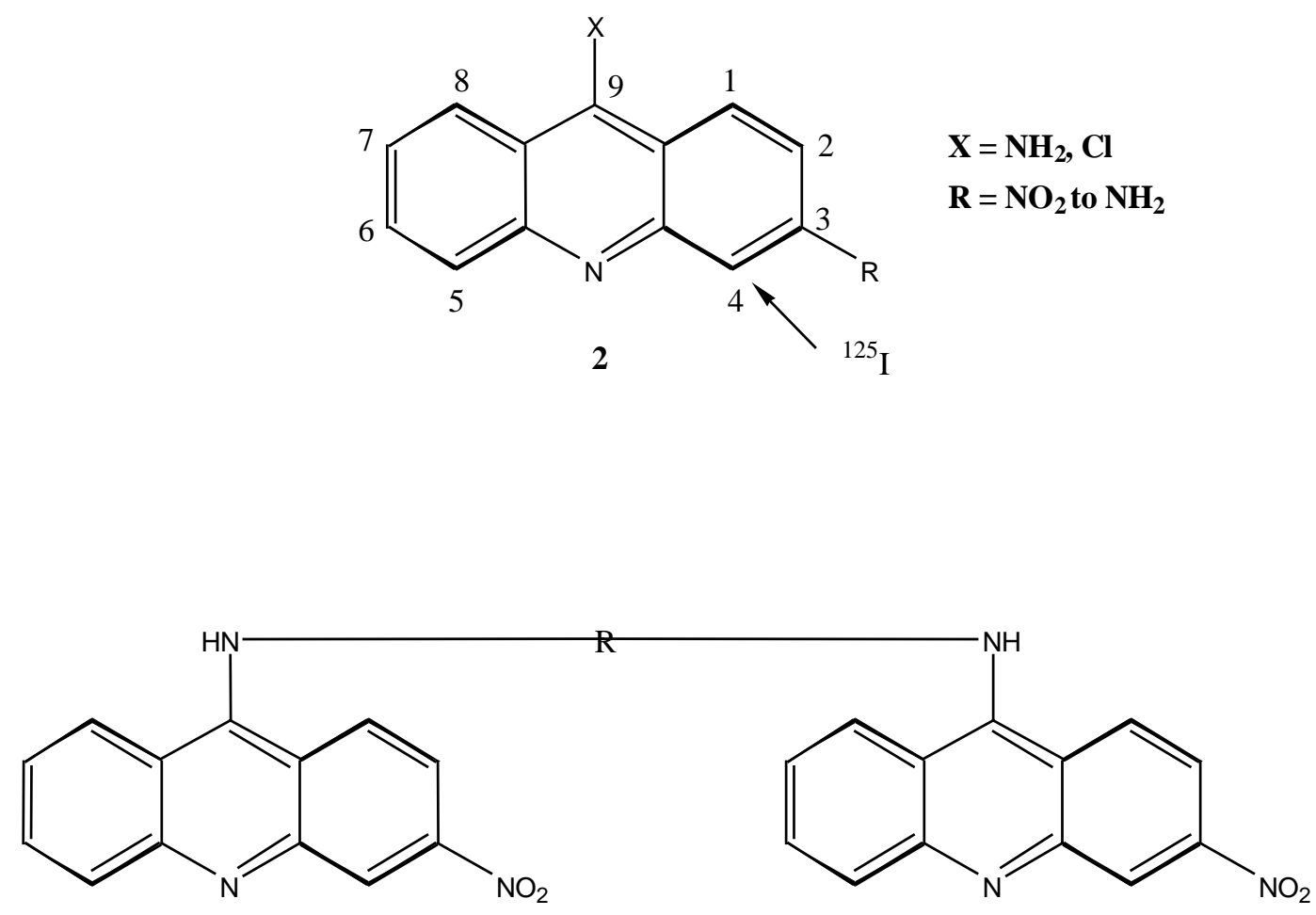

3

It was therefore proposed that the synthesis of bis-acridinyl DNA binding molecules in which the iodine carrier was incorporated into the linker chain would be an attractive alternative. We report here the synthesis of bis-acridine DNA intercalating compounds $\mathbf{4}$ with a spermidine type linker chain incorporating an aromatic ring susceptible to iodination. Motivation for the synthesis of a spermidine type linker molecule stems from previous work performed by Le Pecq and co-workers [3] who carried out the first synthetic work on bis-intercalating compounds. 
Le Pecq showed that the minimum length required of the acridine linker molecule for effective bis-intercalation into DNA was $10.1 \AA$, i.e. the length of two base pairs along the DNA axis which is in accordance with the "excluded site model" [3]. In order to conform to this criterion it was decided to use two linker molecules, spermidine $(n=4)$ and bis-(3-aminopropyl)amine $(n=3)$, in the synthesis of the target compound 4.

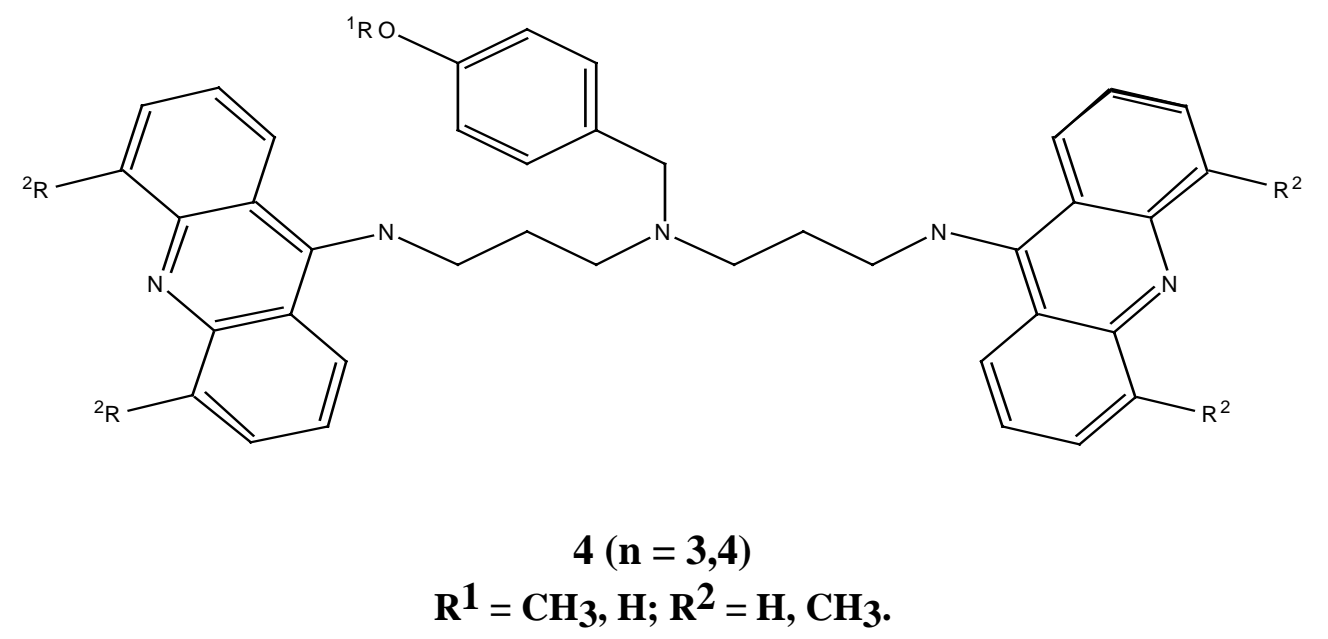

The inclusion of a readily iodinated hydroxybenzyl moiety in the linker chain of $\mathbf{4}$ was proposed in order to take advantage of the use of $125 \mathrm{I}$ labelling and DNA sequencing to identify precisely the nucleotide sequence of highest affinity [13]. Two acridine derivatives, acridine and 4,5dimethylacridine were chosen as the intercalating agents, because both bind strongly to DNA. The 4,5-dimethylacridine derivative bears special significance in that it resembles the active intercalating portion of an effective DNA binding antibiotic antibiotic, actinomycin-D (5) which is known to inhibit transcription. Both 4,5-dimethylacridine and actinomycin-D have methyl substituents at the C-4 and C-5 positions of their respective tricylic rings.

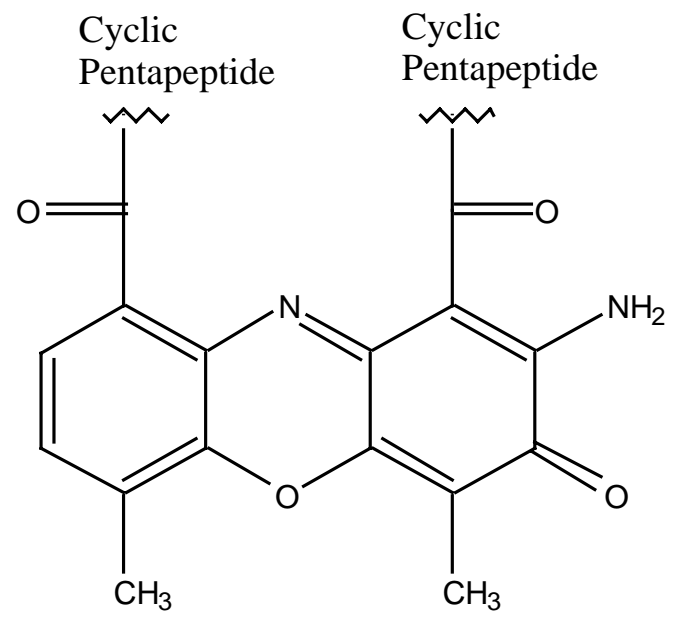




\section{Results and Discussion.}

Previous work carried out in our group by Tassigiannakis [12] resulted in the successful synthesis of $\underline{N}, \underline{N}$-bis-(2-cyanoethyl)-4-methoxybenzylamine (8) and NㅡN-(3-aminopropyl)-4-methoxybenzylamine (9) utilizing step (b) of Scheme 3 and step a of Scheme 4. However the attempted preparation of a bis-aminoacridine by treatment of the bis-amine 9 with 9-chloroacridine proved unsuccessful due to the inherent unreactive nature of 9-chloroacridine. It was therefore decided to continue this synthetic work and explore variations of the scheme in the hope of improving the synthesis towards the target bis-aminoacridine 4, with particular attention given to the coupling step with the acridines.

The synthetic approach to $\underline{\mathrm{N}}, \underline{\mathrm{N}}$-bis-(3-aminopropyl)-4-methoxybenzylamine (9) was patterned on the synthesis of the non-substituted benzylamine compounds by Bergeron and co-workers [14]. Two routes were employed in the synthesis of $\underline{\mathrm{N}}, \underline{\mathrm{N}}$-bis-(2-cyanoethyl)-4-methoxybenzylamine (8), Scheme 3.

\section{Scheme $3^{\mathbf{a}}$}

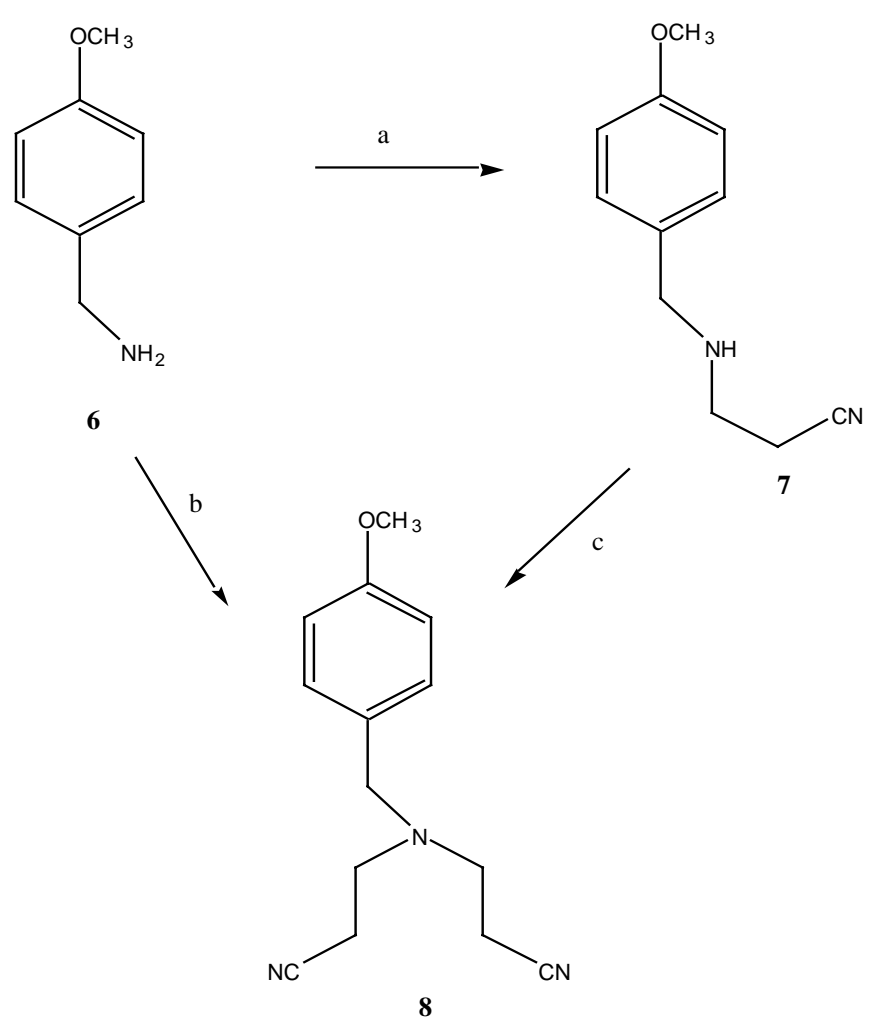

a Reagents: (a) $\mathrm{CH}_{2}=\mathrm{CHCN}$, Room temperature;

(b) $\mathrm{CH}_{2}=\mathrm{CHCN}$, Carius tube $130^{\circ} \mathrm{C} 6$ days;

(c) $\mathrm{CH}_{2}=\mathrm{CHCN}$, Carius tube $125^{\circ} \mathrm{C} 5$ days.

Treatment of methoxybenzylamine $\mathbf{6}$ with acrylonitrile at room temperature afforded the mononitrile (7) in good yield (81\%). The appearance of two triplets at $\delta 2.44$ and $2.88 \mathrm{ppm}$ in the ${ }^{1} \mathrm{H}-$ NMR spectrum was attributed to the C-9 and C-10 methylene protons. Treatment of the mononitrile 7 with excess acrylonitrile and a trace of hydroquinone in a Carius tube [15] (sealed under vacuum) at $125^{\circ} \mathrm{C}$ for five days afforded the dinitrile 8 in $92 \%$ yield. The ${ }^{1} \mathrm{H}-\mathrm{NMR}$ spectrum showed the 
correct integration for the methylene protons of the identical cyanoethyl chains resonating as triplets at $\delta \sigma 2.41$ and $2.84 \mathrm{ppm}$. Hydroquinone, previously omitted from the reaction procedure [14], proved essential in preventing polymerisation of the reaction mixture at such high temperatures.

Synthesis of $\mathbf{8}$ was also achieved in one step by treating 4-methoxybenzylamine with excess acrylonitrile in the presence of hydroquinone in $72 \%$ yield (Scheme 5), comparable to the overall yield above. The dintrile 8 previously reported [12] as a liquid, was obtained as a low melting solid. Subsequent reduction of $\mathbf{8}$ with lithium aluminium hydride and aluminium chloride in diethyl ether gave the bis-amine 9. The ${ }^{1} \mathrm{H}-\mathrm{NMR}$. spectrum revealed a singlet at $\delta 1.57 \mathrm{ppm}$ corresponding to the amine protons.
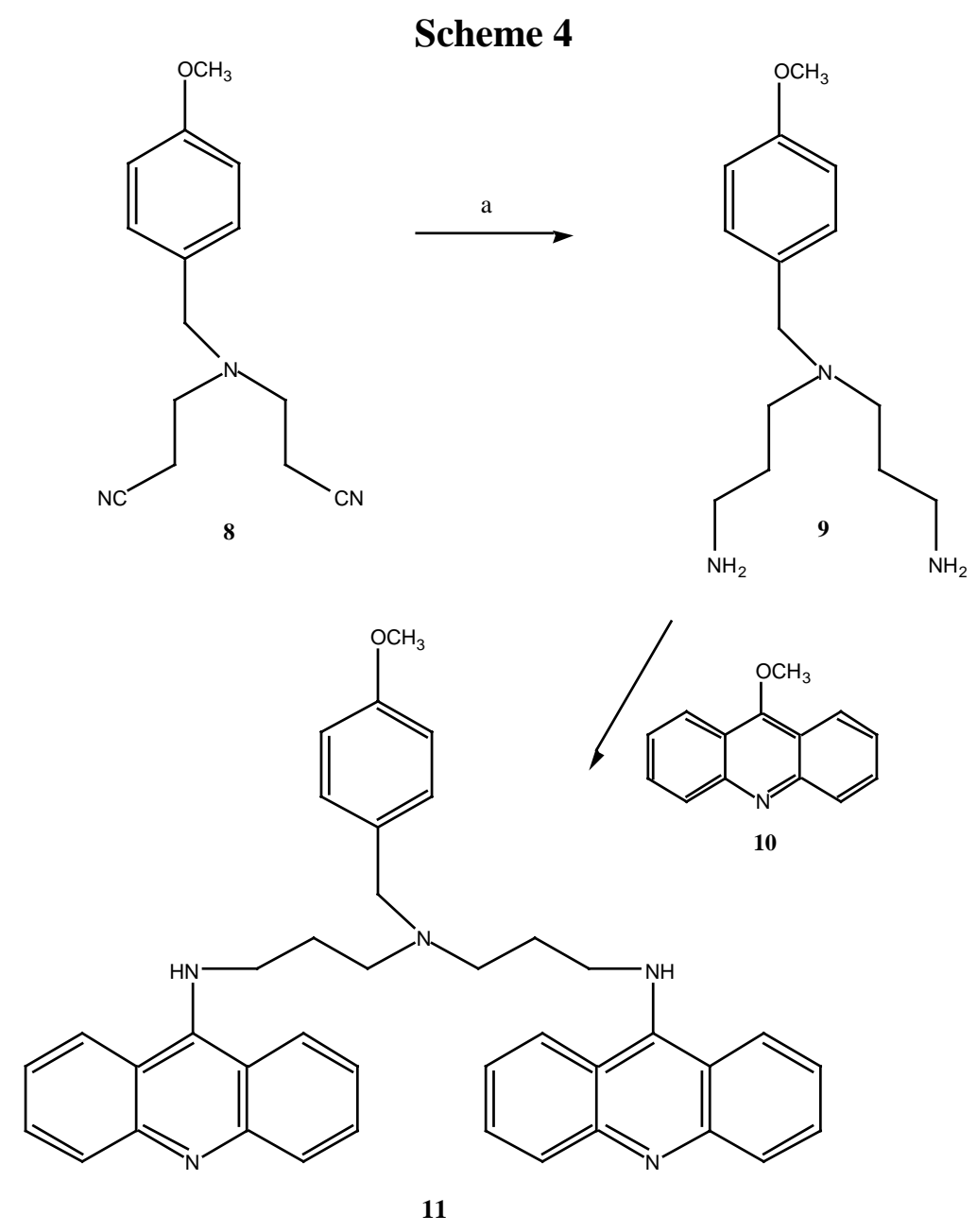

Reagents: (a) $\mathrm{LiAlH}_{4} / \mathrm{AlCl}_{3}$, diethyl ether.

$\underline{\mathrm{N}}^{1}, \underline{\mathrm{N}}^{7}$-bis-(9-acridinyl)-N-(4-methoxybenzyl)-bis-(3-aminopropyl)amine (11) was prepared in good yield by treatment of the bis-amine 9 with two equivalents of 9-methoxyacridine (10) in methanol at room temperature, Scheme $4 .{ }^{13} \mathrm{C}$-NMR spectral analysis revealed that bis coupling of the acridine derivative had occurred, with seven acridine carbon resonances present $(\delta 112.0,119.7$, $122.7,129.3,130.7,133.4,129.9 \mathrm{ppm}$ ) at approximately twice the intensity of the bis-amine methylene carbons. An improvement on previous work [12] was the use of 9-methoxyacridine in the 
coupling reactions rather than 9-chloroacridine. Linking of the acridine moiety by displacement of the methoxy function required only stirring at room temperature whereas high temperatures were required and long reaction times were required for any coupling of the bis-amine to 9-chloroacridine.

The synthesis of $\underline{\mathrm{N}}$-(3-aminopropyl)-N-aminobutyl)-4-methoxybenzylamine (13) outlined in Scheme 5, was based on the synthesis of the non-substituted benzylamine compounds by Bergeron and co-workers [16].

\section{Scheme 5}

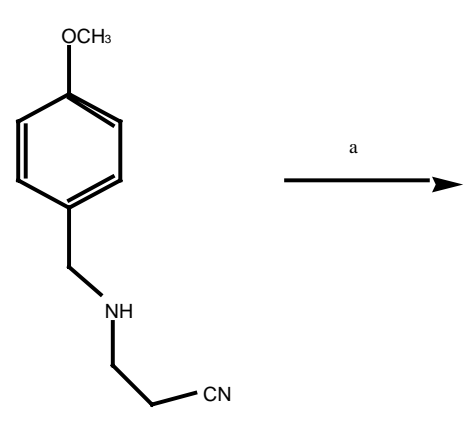

7

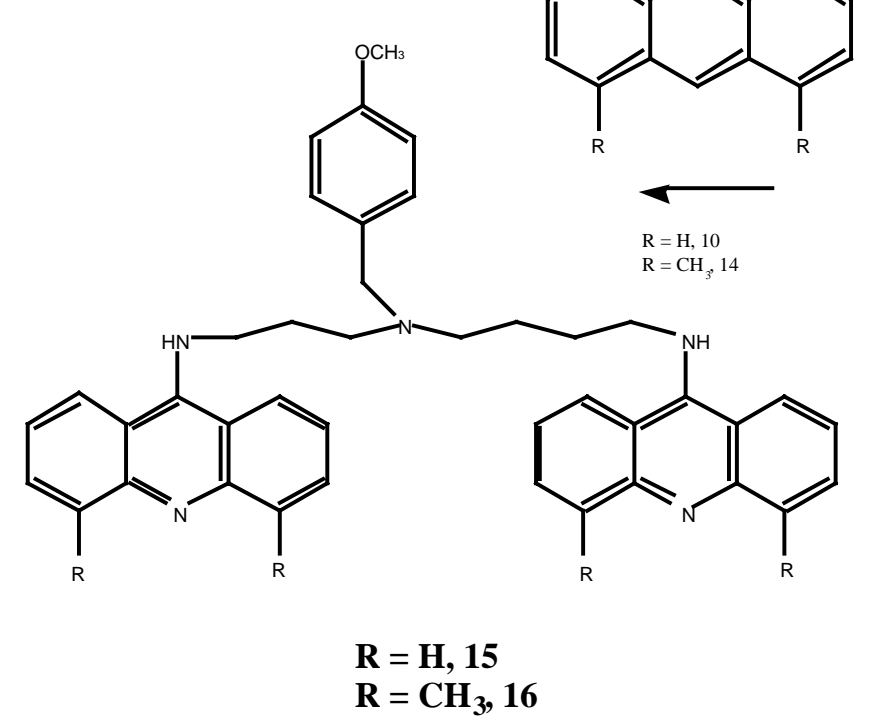

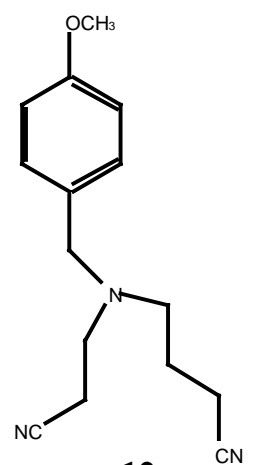

12

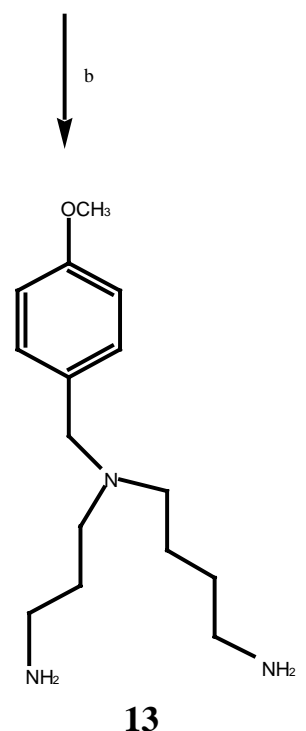

13

Reagents: (a) $\mathrm{ClCH}_{2} \mathrm{CH}_{2} \mathrm{CH}_{2} \mathrm{CN}$, $\mathrm{KI} /$ butanol; (b) $\mathrm{LiAlH}_{4} / \mathrm{AlCl}_{3}$, diethyl ether.

The mononitrile 7, as prepared in Scheme 3, was alkylated with 4-chlorobutyronitrile and potassium iodide in 1-butanol at $117^{\circ} \mathrm{C}$ with potassium carbonate as the base [17], affording the dinitrile 12 in $50 \%$ yield. In addition to the disappearance of the singlet ( $\delta 1.62)$ produced by the secondary amine proton, the ${ }^{1} \mathrm{H}-\mathrm{NMR}$ spectrum contained a doublet of doublets $(\delta 1.79 \mathrm{ppm})$ attributed to the $\mathrm{C}-10$ methylene protons, and a complex multiplet $(\delta 2.35-2.80)$ corresponding to the other eight methylene protons at C-9, C-11, C-13 and C-14. The dinitrile $\mathbf{1 2}$ was reduced in the same 
manner as 8 to yield the bis-amine 13 in $34 \%$ yield. The disappearance of the nitrile ${ }^{13} \mathrm{C}$-NMR signals at $\delta 40.4$ and $42.0 \mathrm{ppm}$ provided positive evidence of the reduction.

Treatment of 13 with 9-methoxyacridine 10 in methanol, afforded the previously unreported bisaminoacridine 15 in $82 \%$ yield. The ${ }^{13} \mathrm{C}$-NMR spectrum was consistent with bis-acridine coupling to the diamine 13 with relatively intense resonances at $\delta 112.9,13.3,113.7,121.6,122.6,124.4,130.6$ and $155.1 \mathrm{ppm}$. In an analogous manner, it was expected that treatment of the bis-amine $\mathbf{1 3}$ with 4,5dimethyl-9-methoxyacridine (14) would result in bis coupling of the acridine derivative to yield the bis-aminoacridine 16. However, coupling proved ineffective even after applying higher temperatures and longer reaction times. Due to low yields of the bis-aminoacridine obtained, conclusive characterisation of the coupled compound was not achieved. The 4,5-dimethylacridine thus appears less reactive towards amines than the unsubstituted acridine $\mathbf{1 0 .}$

9-Methoxyacridine (10) used in the coupling reactions described earlier, is readily synthesised by standard procedures $[18,19]$. The preparation of 4,5-dimethyl-9-methoxyacridine (14) however has not been previously reported. Based on Albert's acridine synthesis [19], this acridine derivative could be obtained via the corresponding 4,5-dimethyl-9-chloroacridine (18). Preparation of 18 was attempted according to the original method Neuman and Powell [20] through an Ullmann condensation of o-bromotoluene and 3-methylanthranilic acid. Isolation of the intermediate condensation product was not successful, however, with the availability of 4,5-dimethylacridone (17) [21] we proceeded to synthesise the desired 9-methoxy compound $\mathbf{1 4}$ by the method outlined in Scheme 6 . Thus treatment of $\mathbf{1 7}$ with phosphorus oxychloride gave 4,5-dimethyl-9-chloroacridine (18) in $84 \%$ yield and subsequent treatment with metallic sodium in methanol afforded the 9-methoxy derivative 14. The appearance of a singlet at $\delta 4.19 \mathrm{ppm}$ in the ${ }^{1} \mathrm{H}-\mathrm{NMR}$ spectrum indicated the presence of a methoxy group.

Scheme 6<smiles>Cc1cccc2c(=O)c3cccc(C)c3[nH]c12</smiles>

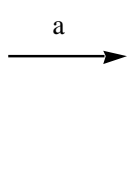<smiles>Cc1cccc2c(Cl)c3cccc(C)c3nc12</smiles><smiles>COc1c2cccc(C)c2nc2c(C)cccc12</smiles>

Reagents: (a) POCl3; (b) $\mathrm{MeO}^{-} \mathrm{Na}^{+} / \mathrm{MeOH}$. 
Although the 4-methoxybenzylmoiety may be iodinated under a variety of conditions, ultimately bis-aminoacridine with a hydroxybenzyl moiety would be more desirable targets since they are more susceptible to iodination. In addition, iodination with ${ }^{125}$ I has to be performed at the final step of the synthesis so the method used must be mild enough so as not to damage the rest of the molecule. Thus a number of demethylation experiments were carried out on $\underline{\mathrm{N}}$-2-(2-cyanoethyl)-N-(3-cyanopropyl)4-methoxybenzylamine (12) with intentions of deprotecting the hydroxy function and reprotecting with a more acid labile protecting group such as tertiary butyl or methoxymethyl. After reduction of the dinitrile 12 to the diamine $\mathbf{1 3}$ and coupling to the acridines, the protecting group could then be easily removed in trifluoroacetic acid to give and analogue of tyrosine, a naturally occurring amino acid.

Demethylation using chlorotrimethylsilane and sodium iodide by Olah's method [22] failed to produce the desired tyrosine analogue. Trimethylsilane appeared to attack the tertiaryamine in preference to the methoxy function. Integration of the multiplet at $\delta 1.61-2.82 \mathrm{ppm}$ in the ${ }^{1} \mathrm{H}-\mathrm{NMR}$ spectrum indicated that the four-carbon nitrile chain had been cleaved. The appearance of a small singlet at $\delta 1.30 \mathrm{ppm}$ corresponds to the proton of the resulting secondary amine. Deprotection of the hydroxybenzyl moiety of $\mathbf{1 2}$ was then attempted using sodium borohydride and iodine according to the method of Long [23]. This procedure also proved unsatisfactory, resulting in cleavage of the long nitrile chain, in addition to the recovery of a small percentage of starting material.

Treatment of $\mathbf{1 2}$ with boron tribromide in dichloromethane as outlined by McOmie and coworkers [24] also failed to produce the tyrosine analogue, resulting in significant decomposition of the dinitrile. Use of a less powerful ether-cleaving agent such as boron trichloride or boron trifluoride has not been attempted.

\section{Future work}

Our future chemistry will involve the synthesis of a more labile protected tyrosine derivative and the subsequent alkylation of the amino group followed by the attachment of the acridine moieties and iodination of the tyrosine moiety to afford the desired iodinated molecule.

\section{Experimental}

\section{General}

Melting points were determined on a Kofler hot stage microscope and are uncorrected. Microanalysis were performed by the AMDEL Australian Microanalytical Service, Melbourne. Infrared spectra were recorded as thin films on sodium chloride discs using a Perkin-Elmer 457 grating spectrophotometer, unless otherwise stated. Electronic absorption spectra were recorded in ethanol using a Varian Super Scan 3 spectrophotometer. Mass spectra were recorded using a VG Micromass 7070F instrument at $70 \mathrm{eV}$. Proton NMR spectra were recorded at $100 \mathrm{MHz}$ using a Jeol FX-100 spectrometer. Sample solutions were prepared in deuterochloroform containing tetramethylsilane as an internal reference. Chemical shifts have been quoted on the $\delta$ scale in p.p.m. relative to tetra- 
methylsilane. Carbon-13 NMR spectra were recorded at $25 \mathrm{MHz}$ using a Jeol FX-100 spectrometer. Deuterochloroform was used as solvent with tetramethylsilane as an internal reference. Chemical shifts were quoted on the $\delta$ scale in p.p.m. relative to tetramethylsilane. All reactions were performed under a dry nitrogen atmosphere. Tetrahydrofuran was distilled from sodium benzophenone ketyl under dry nitrogen immediately before use. Methanol was dried over type $3 \AA$ molecular sieves and distilled from iodine and magnesium turnings immediately before use. 1-Butanol was dried over type $4 \AA$ molecular sieves while all benzene and diethyl ether was sodium dried. Gel filtration was performed on Sephadex LH-20 using 0.005N acetic acid in 4:1 methanol-chloroform as eluent, unless otherwise stated. Preparative thin layer chromatography was performed on Merck Kieselgel 60 GF254 (200-300 mesh). Analytical thin layer chromatography (t.l.c) was performed on Merck Kieselgel $60 \mathrm{GF}_{25}$ precoated plates.

\section{Synthetic methods}

N-(2-cyanoethyl)-4-methoxybenzylamine (7). A mixture of 4-methoxybenzylamine (6) (11.02 g, $80.0 \mathrm{mmol})$ and acrylonitrile $(4.97 \mathrm{~g}, 93.0 \mathrm{mmol})$ was stirred for 45 hours at room temperature. Fractional distillation of the reaction mixture gave N-(2-cyanoethyl)-4-methoxybenzylamine (7) (12.2 g, $81 \%$ ) as a clear oil b.p. $=245^{\circ} \mathrm{C}$ at $0.5 \mathrm{mmHg}$. MS m/z $\left(\mathrm{M}^{+}\right) 190{ }^{1} \mathrm{H}-\mathrm{NMR} \delta 1.6, \mathrm{~s}, \mathrm{NH} ; 2.44, \mathrm{t}$, $\mathrm{J}=5.6 \mathrm{~Hz}, \mathrm{CH}_{2} \mathrm{CN} ; 2.88, \mathrm{t}, \mathrm{J}=6.5 \mathrm{~Hz}, \mathrm{NHCH}_{2} ; 3.70, \mathrm{~s}, \mathrm{PhCH}_{2} ; 3.78, \mathrm{~s}, \mathrm{PhCH}_{2} ; 3.78, \mathrm{~s}, \mathrm{OCH}_{3}$; 7.04, d, J3,5 9.0 Hz, H-3, H-5; 7.26, d, J2,6 9.0 Hz, H-2, H-6. 13C-NMR $\delta 131.5$ (C-1), 129.2 (C-2, C-6), 113.8 (C-3, C-5), 158.0 (C-4), 55.2 (C-7), 52.5 (C-8), 44.2 (C-9), 18.7 (C-10), 118.7 (C-11). Anal. found $\mathrm{C} 69.3, \mathrm{H} 7.5 ; \mathrm{C}_{11} \mathrm{H}_{14} \mathrm{~N}_{2} \mathrm{O}$ requires $\mathrm{C} 69.5, \mathrm{H} 7.4 \%$.

$\underline{N}$-(2-Cyanoethyl)- $\underline{N}$-(3-cyanopropyl)-4-methoxybenzylamined (12) A solution of 4-chlorobutyronitrile $(2.46 \mathrm{~g}, 25.0 \mathrm{mmol})$ in anhydrous n-butanol $(9.1 \mathrm{~mL})$ was added over 2 hours to a mixture of $\mathrm{N}$-(2-cyanoethyl)-4-methoxybenzylamine (5.07 g, $40.0 \mathrm{mmol})$, anhydrous sodium carbonate $(4.22 \mathrm{~g}, 40.0 \mathrm{mmol})$ and potassium iodide $(0.64 \mathrm{~g}, 4.0 \mathrm{mmol})$ at $117^{\circ} \mathrm{C}$. The mixture was stirred for an additional 20.5 hours at $117^{\circ} \mathrm{C}$. After cooling to room temperature, the mixture was filtered and the solid washed with diethyl ether. The combined filtrate and washing were extracted with $3 \mathrm{~N} \mathrm{HCl}(3 \mathrm{x} 40 \mathrm{~mL})$ and the resulting acid solution was washed with ether $(2 \mathrm{x} 40 \mathrm{~mL})$, made basic with potassium carbonate and extracted with ether $(3 \times 70 \mathrm{~mL})$. The final ethereal extracts were dried over sodium sulphate, filtered and evaporated to give an oil (4.45 g, 50.0\%). Subsequent distillation afforded $3.24 \mathrm{~g}(43.3 \%)$ of the desired $\mathrm{N}$-(2-cyanoethyl)-N-(3-cyanopropyl)-4methoxybenzylamine (12) as a light yellow oil b.p. $=235^{\circ}$ at $0.06 \mathrm{mmHg} . \mathrm{MS} \mathrm{m} / \mathrm{z} 257\left(\mathrm{M}^{+}\right) ;{ }^{1} \mathrm{H}-$ NMR $\delta 1.79$, q, , J $6.0 \mathrm{~Hz}, \mathrm{CH}_{2} \mathrm{CH}_{2} \mathrm{CH}_{2}, 2.46, \mathrm{~m}, 2$ x NCH 2,2 x CH $2 \mathrm{CN}, 3.54, \mathrm{~s}, \mathrm{PhCH}_{2}, 3.79$, s, $\mathrm{OCH}_{3}, 6.87$, d, , J 9.0 Hz, H-3, H-5, 7.23, d, , J 9.0 Hz, H-2, H-6. 13C-NMR $\delta 113.7$ (C-1), 129.7 (C2, C-6), 113.9 (C-3, C-5), 158.9 (C-4), 57.8 (C-7), 55.2 (C-8), 49.2 (C-9), 14.6 (C-10), 119.7 (C-11), 51.8 (C-12), 23.4 (C-13), 118.9 (C-15). Anal. found $\mathrm{C} 69.7, \mathrm{H} 7.3, \mathrm{~N} 16.2 ; \mathrm{C}_{15} \mathrm{H}_{19} \mathrm{~N}_{3} \mathrm{O}$ requires $\mathrm{C}$ 70.0, H 7.3, N $16.3 \%$. 
$\underline{N}$-(3-Aminopropyl)- $\underline{N}$-(4-aminobutyl)-4-methoxybenzylamine (13). A solution of anhydrous aluminium chloride $(2.04 \mathrm{~g}, 15.3 \mathrm{mmol})$ in anhydrous diethyl ether $(21 \mathrm{~mL})$ was rapidly added to a suspension of lithium aluminium hydride $(0.6 \mathrm{~g}, 15.8 \mathrm{mmol})$ in anhydrous ether $(30 \mathrm{~mL})$. After vigorous stirring of the mixture, a solution of $\mathrm{N}$-(cyanoethyl)- $\mathrm{N}$-(cyanopropyl)-4-methoxy benzylamine (12) (1.47 g, $6.0 \mathrm{mmol})$ in anhydrous diethyl ether $(21.0 \mathrm{~mL})$ was added over 2 hours and the reaction was stirred at room temperature for 29 hours. The solution was cooled to $0^{\circ} \mathrm{C}$, quenched with $30 \%$ aqueous potassium hydroxide $(\mathrm{w} / \mathrm{v} ; 30 \mathrm{~mL})$ and the ethereal layer decanted. The combined ethereal extracts were washed with cold saturated aqueous sodium chloride $(2 \times 25$ $\mathrm{mL}$ ). Evaporation of the diethyl ether gave a light brown oil which was taken up in chloroform (60 $\mathrm{mL}$ ), dried over anhydrous magnesium sulphate, filtered and the chloroform evaporated under reduced pressure. A crude oil was obtained $(0.73 \mathrm{~g})$ which upon fractional distillation afforded 0.52 $\mathrm{g}(34 \%)$ of the desired $\underline{\mathrm{N}}$-(3-aminopropyl)-N-(4-aminobutyl)-4-methoxybenzylamine (13) as a light yellow oil. MS m/z $265\left(\mathrm{M}^{+}\right)$; ${ }^{1} \mathrm{H}-\mathrm{NMR} \delta 1.12$, s, 2 x NH $2,1.49$, m, 2 x (H-10, H-11, H-14), 2.50, m, 2 x (H-9, H-12, H-13, H-15), 3.47, s, $\mathrm{PhCH}_{2}$, 3.79, s, OCH3 , 7.20, d, , J 10 Hz, H-2, H-6. Anal. found $\mathrm{C} 67.9, \mathrm{H} 10.0, \mathrm{~N} 16.2 ; \mathrm{C}_{15} \mathrm{H}_{27} \mathrm{~N}_{3} \mathrm{O}$ requires $\mathrm{C} 67.9, \mathrm{H} 10.2, \mathrm{~N} 15.8 \%$.

$\underline{N}^{1}, \underline{N}^{8}$-Bis-(9-acridinyl)- $\underline{N}^{4}$-(4-methoxybenzyl)spermidine (15). Nㅡ-(3-aminopropyl)-N-(4-aminobutyl)-4-methoxybenzylamine 13 (0.34 g, $128 \mathrm{mmol})$ was dissolved in methanol $(2.0 \mathrm{~mL})$ and added to 9 -methoxyacridine $\mathbf{1 0}(0.54 \mathrm{~g}, 2.39 \mathrm{mmol})$. The mixture was stirred for 70 hours at $30^{\circ} \mathrm{C}$, the methanol was evaporated under reduced pressure followed by gel filtration to afford $250 \mathrm{mg}(30 \%)$ of the desired bis-aminoacridine 15 as an orange gum. ${ }^{1} \mathrm{H}-\mathrm{NMR} \delta 1.5-3.3, \mathrm{~m}, 7 \times \mathrm{CH}_{2}, 2.22$, s, $2 \mathrm{x}$ $\mathrm{NH}, 3.55, \mathrm{~s}, \mathrm{PhCH}_{2}, 3.71, \mathrm{~s}, \mathrm{OCH}_{3}$ ), 7.02-7.96, m, H-2, H-6, H-3, H-5, and acridine protons, $20 \mathrm{H}$. Anal. found $\mathrm{C} 70.1, \mathrm{H} 6.7 ; \mathrm{C}_{41} \mathrm{H}_{41} \mathrm{~N}_{5} \mathrm{O}$ requires $\mathrm{C} 69.5, \mathrm{H} 5.9 \%$.

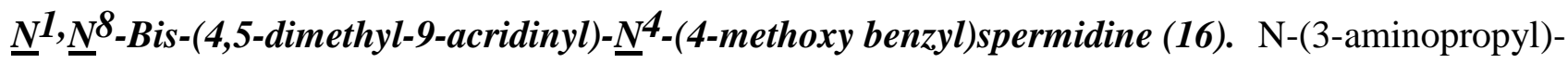
$\mathrm{N}$-(4-aminobutyl)-4-methoxybenzylamine 13 (60 $\mathrm{mg}, 0.23 \mathrm{mmol}$ ) was dissolved in tetrahydrofuran $(1.0 \mathrm{~mL})$ and added to 4,5-dimethyl-9-methoxyacridine (14) $(85 \mathrm{mg}, 0.18 \mathrm{mmol})$. The mixture was stirred for 48 hours at room temperature, then stirred at $35^{\circ} \mathrm{C}$ for 8 hours. Evaporation of the tetrahydrofuran under reduced pressure followed by gel filtration afforded the desired $\underline{N}^{1}, \underline{N}^{8}$-bis-(4,5-

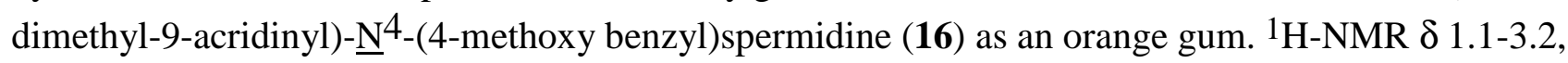
$\mathrm{m}, 8 \times \mathrm{CH}_{2}, 2.21$, s, $2 \times \mathrm{PhCH}_{3}, 3.42$, s, OCH3 $, 7.02-7.81, \mathrm{~m}, \mathrm{H}-2, \mathrm{H}-6, \mathrm{H}-3, \mathrm{H}-5$ and acridine protons. UV ( $\log \mathrm{E}), 226,266,398$ (4.02, 3.86, 3.0). $\mathrm{v}_{\max }$ 3400, 2950, 2150, 1570, 1410, 1250, $1180,1025 \mathrm{~cm}^{-1}$.

$\underline{N}, \underline{N-B i s-(2-c y a n o e t h y l)-4-m e t h o x y b e n z y l a m i n e ~(8): ~ M e t h o d ~ 1:-A ~ m i x t u r e ~ o f ~ 4-m e t h o x y b e n z y l-~}$ amine $(0.406 \mathrm{G}, 2.9 \mathrm{mmol})$, an excess of acrylonitrile $(0.85 \mathrm{~g}, 16.0 \mathrm{mmol})$ and a trace of hydroquinone was added to a Carius tube [15]. The tube was sealed under vacuum $(0.1 \mathrm{mmHg})$ and the tube was heated at $45^{\circ}$ for 8 hours, then $130^{\circ} \mathrm{C}$ for 140 hours. The resulting amber brown liquid was distilled under vacuum to afford $0.53 \mathrm{~g}(72 \%)$ of the desired N,N-bis-(2-cyanoethyl)-4-methoxybenzylamine $(8)$ as a colourless oil. b.p. $=225^{\circ} \mathrm{C}$ at $0.21 \mathrm{mmHg}$, which formed a white solid, m.p. $=$ $48^{\circ} \mathrm{C}$ on cooling to room temperature. 
Method 2:- A mixture of N-(2-cyanoethyl)-4-methoxybenzylamine 7 (1.63 g, $8.6 \mathrm{mmol})$, an excess of acrylonitrile ( $1.69 \mathrm{~g}, 31.8 \mathrm{mmol}$ ) and a trace of hydroquinone was added to a Carius tube. The tube was sealed under vacuum $(0.3 \mathrm{mmHg})$ and heated at $125^{\circ}$ for 144 hours. The resulting brown oil was distilled under vacuum to afford $1.93 \mathrm{~g}(92.4 \%)$ of the desired N,N-bis-(2-cyanoethyl)-4methoxybenzylamine $(8)$ as a light yellow oil. b.p. $=220^{\circ} \mathrm{C}$ at $0.2 \mathrm{mmHg}$. $\mathrm{MS} \mathrm{m} / \mathrm{z} 243\left(\mathrm{M}^{+}\right) ;{ }^{1} \mathrm{H}-$ NMR $\delta$ 2.41, t, 2 x (H-10, H-13), J 6.6 Hz, 2.84, t, 2 x (H-9, H-12), J 6.0 Hz, 3.6, s, PhCH2), 3.77, s, $\mathrm{OCH}_{3}, 6.85$, d, , J 9.0 Hz, H-2, H-6, 6.89, d, , J 8.6 Hz, H-3, H-5, 7.20, d, , J 10 Hz, H-2, H-6. ${ }^{3} \mathrm{C}-$ NMR $\delta 116.0$ (C-1), 129.8 (C-2, C-6), 113.9 (C-3, C-5), 159.1 (C-4), 57.4 (C-7), 55.2 (C-8), 49.2 (C9), 16.7 (C-10), 118.8 (C-11), $49.2(\mathrm{C}-12), 16.7(\mathrm{C}-13)$. Found $\mathrm{M}^{+} .=243.135 ; \mathrm{C}_{14} \mathrm{H}_{17} \mathrm{~N}_{3} \mathrm{O}$ requires $\mathrm{M}^{+} .=243.137$.

$\underline{N}, \underline{N}$-Bis-(3-aminopropyl)-4-methoxybenzylamine (9):- A solution of aluminium chloride (2.66 g, $19.8 \mathrm{mmol})$ in anhydrous diethyl ether $(25 \mathrm{~mL})$ was rapidly added to a suspension of lithium aluminium hydride $(0.75 \mathrm{~g}, 19.8 \mathrm{mmol})$ in anhydrous diethyl ether $(35 \mathrm{~mL})$. The mixture was

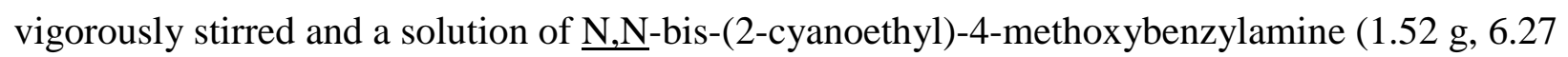
$\mathrm{mmol})$ in anhydrous diethyl ether $(25 \mathrm{~mL})$ was added over 1.5 hours. After stirring at room temperature for 50 hours the mixture was cooled to $0^{\circ}$, quenched with aqueous $30 \%$ potassium hydroxide $(\mathrm{w} / \mathrm{v} ; 30 \mathrm{~mL})$ and the ethereal layer decanted. The remaining emulsion was extracted with diethyl ether $(4 \times 100 \mathrm{~mL})$ and the combined diethyl ether extracts washed with saturated aqueous sodium chloride $(2 \times 25 \mathrm{~mL})$. Evaporation of the diethyl ether under reduced pressure gave a brown oil which was taken up in chloroform $(50 \mathrm{~mL})$, dried over anhydrous magnesium sulphate, filtered and the chloroform evaporated under reduced pressure. Fractional distillation of the resulting oil afford $0.391 \mathrm{~g}(25 \%)$ of the desired $\underline{\mathrm{N}}, \underline{\mathrm{N}}$-bis-(3-aminopropyl)-4-methoxybenzylamine (9) as a light yellow oil. b.p. $=190^{\circ}$ at $0.4 \mathrm{mmHg} . \mathrm{MS} \mathrm{m} / \mathrm{z} 251\left(\mathrm{M}^{+}\right) ;{ }^{1} \mathrm{H}-\mathrm{NMR} \delta 1.57, \mathrm{~s}, 2 \times \mathrm{NH}_{2}, 2.37-2.68, \mathrm{~m}$, 6 x CH $2,3.72$, s, $\mathrm{PhCH}_{2}, 3.79$, s, $\mathrm{OCH}_{3}, 6.85$, d, , J 9.0 Hz, H-2, H-6, 7.22, d, , J 9.0 Hz, H-3, H-5. $\mathrm{UV}(\log \mathrm{E}) 271 \mathrm{~nm}(3.20)$. Found $\mathrm{M}^{+} .=251.19975 ; \mathrm{C}_{14} \mathrm{H}_{25} \mathrm{~N}_{3} \mathrm{O}$ requires $\mathrm{M}^{+} \cdot=251.19975$.

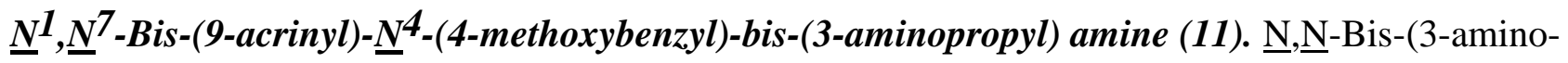
propyl)-4-methoxybenzylamine $(9)(40.0 \mathrm{mg}, 0.16 \mathrm{mmol})$ was dissolved in methanol $(1.5 \mathrm{~mL})$, added to 9-methoxyacridine (10) $(66.0 \mathrm{mg}, 0.32 \mathrm{mmol})$ and the mixture was stirred at room temperature for 63 hours. Evaporation of the methanol under reduced pressure, followed by gel filtration afforded $88.0 \mathrm{mg}(91 \%)$ of the desired $\underline{N}^{1}, \underline{N}^{7}$-bis-(9-acrinyl)- $\underline{N}^{4}$-(4-methoxybenzyl)-bis-(3-aminopropyl) amine (11) as an orange-red gum. ${ }^{1} \mathrm{H}-\mathrm{NMR} \delta 2.17, \mathrm{~s}, 2 \mathrm{x} \mathrm{NH}, 2.31-3.65, \mathrm{~m}, 6 \times \mathrm{CH}_{2}$ ), 3.74, s, $\mathrm{PhCH}_{2}, 3.80, \mathrm{~s}, \mathrm{OCH}_{3}, 6.82-7.61, \mathrm{~m}, \mathrm{H}-3, \mathrm{H}-5, \mathrm{H}-2, \mathrm{H}-6$ and acridine protons, $20 \mathrm{H}$; UV (log E) $225,267,414$ nm. 4.3, 4.45, 4.36. Found $\mathrm{M}^{+} .=605.31543 ; \mathrm{C}_{40} \mathrm{H}_{39} \mathrm{~N}_{5} \mathrm{O}$ requires $\mathrm{M}^{+} .=605.31543$.

9-Chloroacridine (21). Prepared from 2-carboxydiphenylamine (1.0 g, $4.6 \mathrm{mmol})$ and freshly distilled phosphorus oxychloride $3.0 \mathrm{~mL}, 32.7 \mathrm{mmol}$ ) according to Albert [19] and obtained as pale yellow crystals $(0.37 \mathrm{~g}, 37 \%)$. M.p. $=120^{\circ} \mathrm{C}$ (lit [27] $\left.=120^{\circ} \mathrm{C}\right) . \mathrm{MS} \mathrm{m} / \mathrm{z} 215\left(\mathrm{M}^{+}\right)$. 
9-Methoxyacridine (10). Prepared from 9-chloroacridine $(0.5 \mathrm{~g}, 2.4 \mathrm{mmol})$ and a sodium methoxide solution generated from sodium $(0.1 \mathrm{~g}, 4.4 \mathrm{mmol})$ in methanol $(5.8 \mathrm{~mL})$ by the method of Albert [19] and obtained as dark yellow crystals. Recrystallisation from light petroleum $\left(60-80^{\circ} \mathrm{C}\right)$ afforded 0.31 $\mathrm{g}(63 \%)$ of the desired 9-methoxyacridine $(\mathbf{1 0})$ as pale yellow crystals, m.p. $=99-101^{\circ} \mathrm{C}$ (lit $[19]=$ $\left.103^{\circ} \mathrm{C}\right) .{ }^{1} \mathrm{H}-\mathrm{NMR} \delta 4.26, \mathrm{~s}, \mathrm{OCH}_{3}, 8.0, \mathrm{~m}$, acridine protons.

4,5-dimethyl-9-chloroacridine (18). 4,5-dimethylacridone (20) (1.0 g, $4.5 \mathrm{mmol})$ and freshly distilled phosphorus oxychloride $(7.0 \mathrm{~mL})$ were refluxed at $130^{\circ} \mathrm{C}$ for 1.5 hours. Unused phosphorus oxychloride was then distilled off under reduced pressure. The residue was allowed to cool and then thinned with chloroform $(10.0 \mathrm{~mL})$. The solution was then poured into a mixture of ice $(40.0 \mathrm{~g})$ and concentrated aqueous ammonia $(33 \%)(10.0 \mathrm{~mL})$ with heat being liberated. The solution was stirred, the chloroform layer separated and the aqueous phase extracted with chloroform $(2 \times 30 \mathrm{~mL})$. The combined chloroform extracts were dried over anhydrous magnesium sulphate, filtered and the chloroform evaporated under reduced pressure to give a yellow powder which upon recrystallisation from petroleum ether (b.p. $60-80^{\circ} \mathrm{C}$ ) afforded $0.83 \mathrm{~g}(84 \%)$ of the desired 4,5-dimethyl-9-chloroacridine (21) as yellow-green needles m.p. $=150-151^{\circ} \mathrm{C}$ (lit [29] 151-152 $\left.{ }^{\circ} \mathrm{C}\right) . \mathrm{MS} \mathrm{m} / \mathrm{z} 241\left(\mathrm{M}^{+}\right)$; ${ }^{1} \mathrm{H}-\mathrm{NMR} \delta 2.94, \mathrm{~s}, 2$ x CH $3,7.42-8.31$, m, acridine protons.

4,5-Dimethyl-9-methoxyacridine (14). 4,5-Dimethyl-9-chloroacridine (220 mg, $0.91 \mathrm{mmol}$ ) was added to a methoxide solution generated from sodium $(160 \mathrm{mg}, 6.95 \mathrm{mmol})$ in methanol $(15.0 \mathrm{~mL})$ and tetrahydrofuran $(0.5 \mathrm{~mL})$. The solution was gently refluxed for 40 hours and allowed to cool and the methanol reduced under vacuum. The residue was taken up in benzene, filtered from the salt and the benzene evaporated under reduced pressure to give a yellow powder which was recrystallised from heptane to afford $145 \mathrm{mg}(67 \%)$ of the desired 4,5-dimethyl-9-methoxyacridine (14) as yellow crystals m.p. $=90-91^{\circ} \mathrm{C} . \mathrm{MS} \mathrm{m} / \mathrm{z} 237\left(\mathrm{M}^{+}\right) ;{ }^{1} \mathrm{H}-\mathrm{NMR} \delta 2.93(6 \mathrm{H}, \mathrm{s}, 2$ x CH 3$), 4.19\left(3 \mathrm{H}, \mathrm{s}, \mathrm{OCH}_{3}\right)$, 7.32-8.17 (6H, m, acridine protons). Anal. Found $\mathrm{C} 80.0, \mathrm{H} 6.4, \mathrm{~N} 5.9 \%$; $\mathrm{C}_{16} \mathrm{H}_{15} \mathrm{NO}$ requires $\mathrm{C}$ 80.6, H 6.4, N 5.9\%. UV (log E) 225, 357, 373, 392 nm. (4.63, 3.81, 3.80, 3.66).

\section{References}

1. Blake, A., and Peacocke, A. R., Biopolymers, 1961, 6, 1225.

2. Lerman L. S., J. Mol. Biol., 1961, 3, 18-20.

3. Le Pecq, J. B., Le Bret, M., Barbet, J., and Roques, B., Proc. Natl. Acad. Sci. U.S.A. 1977, 72, 2915-2199.

4. Sakore, T. D., Jain, S. C., Tsai, C and Sobell, H. M., Proc. Natl. Acad. Sci. U.S.A. 1962, 74, 188.

5. Waring, M. J. Mol. Biol., 1970, 54, 247.

6. Hurwitz, J. Furth, J., Malamy, M and Alexander, M. Proc. Natl. Acad. Sci. U.S.A. 1962, 48, 1222.

7. Martin, R. F. and Kelly, D. P., Aust. J. Chem., 1979, 32, 2637-2646.

8. Martin, R.F., Int. J. Radiat. Biol., 1977, 32, 553. 
9. Krish, R. E and Sauri, C. J., Int. J. Radiat. Biol. 1975, 27, 553-560.

10. Wakelin, L. P. G., Creasy, T. S and Waring, M. J., FEBS Lett., 1979, 104, 261-265.

11. Shultz, P. G., Dervan, P. B., J. Am. Chem. Soc., 1983, 105, 7748-7750.

12. Tassigiannakis, W., B.Sc.(Hons.) Thesis, University of Melbourne., 1982.

13. Martin, R. F., and Holmes, N., Nature, 1983, 302, 452-454.

14. Bergeron, R. J., Burton, P. S., McGovern, K. A., Kilne, S. J., Synthesis (Comm)., 1981, 731733.

15. Cannellakis, E. S., Shaw, Y. H., Hanmers, W. E and Sahartz, R. A., Biochem. et Biophys. Acta., 1976, 418, 277-289.

16. Bergeron, R. J., McGovern, K. A., Channing, M. A and Burton, P.S., Synthesis (Comm)., 1980, 45, 1589-1592.

17. Bruson, H. A., Org React., 1949, 5, 79.

18. Acheson, R. M., 'Acridines', 2nd Ed. (J. Wiley and Sons: New York, 1973).

19. Albert, A., 'The Acridines' 2nd Ed. (Edward Arnold Publishers: London, 1966).

20. Newman, M. S and Powell, W. H., J. Org. Chem., 1961, 26, 812-815.

21. Cain, B. F and Atwell, G. J., J. Med. Chem., 1976, 19, 1124-1129.

22. Olah, G. A., Narang, S. C., Gupta, G. B and Malhotra, R., Tetrahedron, 1969, 44, 1247.

23. Long, L. H and Freeguard, G. F., Chem and Ind. (London), 1965, 223.

24. McOmie, J.F.W., Watts, M. L and West, D. E., Tetrahedron, 1969, 24, 2289.

25. Kluge, A. F., Untch, K. G and Fried, J. H., J. Am. Chem. Soc., 1972, 94, 7827.

26. Gould, F. E., Johnson, G. S and Ferris, A. F., J. Org. Chem., 1960, 25, 1658-1660.

27. Brown, H. C., Choi, Y. M and Narasimhan, S., J. Org. Chem., 1982, 47, 3153-3163.

28. Allen, C. F. H and McKee, G. H. W., Org. Synth., 1939, 19, 6-9.

29. Albert, A and Gledhill, W. J., J. Soc. Chem. Indust., 1942, 61, 159-160.

Sample Availability: Samples are available from the authors.

(C) 2001 by MDPI (http://www.mdpi.org). Reproduction is permitted for noncommercial purposes 